\title{
Editorial: protecting and sustaining indigenous people's traditional environmental knowledge and cultural practice
}

\author{
Amanda H. Lynch • Craig S. Hammer
}

Published online: 11 April 2013

(C) Springer Science+Business Media New York 2013

As applied to the circumstances faced by particular indigenous communities - from the Yorta Yorta of Australia to the Bhotiya of Nepal—and to indigenous communities around the world, the five intellectual tasks of the policy sciences enable the authors in this special issue to clarify the values and goals of the participants, and whether and how they relate to the protection of human dignity, as a critical first step toward developing an effective strategy to combat an evident wrong. This initial inquiry raises what Lasswell termed the "historical question" $(1963,2)$, and so each analysis in this issue was informed by an examination of the events and conditioning factors over time in relation to the realization of the goals identified. In the light of this "trend and factor knowledge" (Lasswell 1963, 2), the authors have been able to explore the ways in which future developments might unfold and policy alternatives can be devised. Each contributor to this special issue has thus addressed an aspect of the question of the role of indigenous peoples' knowledge and practices for a range of outcomes including poverty alleviation for indigenous peoples and the sustainable management of biodiversity, among others. The intention is to raise important questions on juxtaposing human rights with the collaborative development of culturally sensitive strategies through which indigenous peoples may move closer to the realization of sustainable self-determination and human dignity.

For millennia, the Earth's geophysical environment has co-evolved with the biosphere, resulting in a diversity of uniquely adapted species and systems, and ultimately fostering human civilization. The twentieth century saw the emergence of human beings as the dominant catalyst of change in the earth system-by almost any measure we have begun a

The views expressed are those of the authors and do not represent those of The World Bank Group or its Board of Directors.

\footnotetext{
A. H. Lynch $(\bowtie)$ Box 1951, Providence, RI 02912, USA

e-mail: amanda_lynch@brown.edu

C. S. Hammer

The World Bank, 1818 H St NW, Washington, DC 20433, USA

e-mail: chammer@worldbank.org
}

Environmental Change Initiative, Department of Geological Sciences, Brown University, 
geologic era aptly termed the Anthropocene (Crutzen and Steffen 2003). The number of human beings has surpassed 7 billion, all of whom are dependent on continued access to natural resources from across the planet for the production of, among other things, food, fuel, fertilizer, timber, and medicines (Secretariat of the Convention on Biological Diversity 2004). Local, national, and international organizations have recognized indigenous knowledge as essential to addressing complex environmental problems. Many have demonstrated that such knowledge often facilitates decision-making in ways that are diversified, risk-averse, and cost-effective (Vanek 1989; Hansen and Erbaugh 1987; Dei 1993; Beckford et al. 2010). These positive outcomes are attributed to knowledge and practice rooted in a community's traditions, incrementally refined over time and transmitted between generations, highly contextual with regard to the natural resources in and features of a particular geographical area. From the point of view of many indigenous communities, their knowledge and practices are vested with cultural, material, psychological, and spiritual significance. Several indigenous peoples-including those participating in the Symposium that was part of the Society of Policy Scientists Annual Institute in 2011-have understood that their survival is conditioned by their ability to sustain their cultural practices and is linked to their dependence on their land and resources.

The purpose of the 2011 Symposium and this special issue that arose from it is to explore indigenous ways of knowing and practices, and their relationship to biodiversity and to patrimonial land itself, through the lens of the policy sciences. The problem orientation of the policy sciences emphasizes the conditions and consequences of human exchanges: the rules, norms, precepts, and concepts which govern human interaction is fleshed out by focusing on the actors themselves, their relationships with others, and the contexts in which they act (McDougal et al. 1968). Most importantly, under the policy sciences framework, the achievement of human dignity is of paramount importance (Lasswell and McDougal 1943). These concepts are explored in the following five articles, as introduced below.

In their article "The role of the Yorta Yorta people in clarifying the common interest in sustainable management of the Murray-Darling Basin, Australia," Amanda Lynch, David Griggs, Lee Joachim, and Jackie Walker assay the common interest inherent in a shared regional governance regime for the Murray-Darling Basin in Australia—comprising both the spiritual center of the traditional owners, the Yorta Yorta and a national agricultural industry worth approximately AUS\$9 billion per year-by state authorities and the Yorta Yorta people themselves. The authors document that, through their traditional law, the Yorta Yorta have a strong interest in sharing their knowledge and practices to achieve more than personal interests, with regard to both the sustainability of the Basin ecosystem and the people who rely on it. To this end, human dignity - the overarching goal of the Policy Sciences - can be disaggregated: It can open the door to the achievement of the common interest through more responsible stewardship of the Basin and its biodiversity-in the light of the Yorta Yorta's deep knowledge of the region, honed over generations - and also by better enabling the Yorta Yorta to achieve more equitable treatment under national law, thereby becoming more active agents of their own social and economic development.

In "Practical Developments in Law Science and Policy: Efforts to Protect the Traditional Group Knowledge and Practices of the Shuar, an Indigenous People of the Ecuadorian Amazon," Craig Hammer, Juan Carlos Jintiach, and Ricardo Tsakimp explore different dimensions of the use (and misuse) of indigenous people's knowledge for harvesting biodiversity through the lens of relatively recent experiences of the Shuar indigenous people of the Amazon Basin. The Shuar peoples' knowledge was misappropriated by bio-prospectors - a centuries-old phenomenon that views the traditional knowledge of 
indigenous societies as a direct route to useful plant and animal extracts with valuable pharmaceutical potential. The authors explore both the misappropriation and the development of a fair and equitable strategy to combat further attempts by outsiders to appropriate the Shuar's traditional knowledge. The authors highlight that the Shuar-like the Yorta Yorta-are mindful of the significant beneficial implications of their traditional knowledge for the betterment of humanity; they, like many other indigenous communities, very much want to contribute to humanity as they seek to protect their intellectual property rights over the knowledge itself (International Alliance of Indigenous-Tribal Peoples of the Tropical Forests 1992).

Winston Nagan conducts a detailed analysis in "Protecting the Economic Patrimony of Indigenous Nations: The Case of the Shuar" of the growing corpus of legal standards and protections specifically afforded to indigenous peoples' knowledge and practices as it relates to biodiversity on their patrimonial land, as well as whether and how those regimes developed for non-indigenous stakeholders could be extended to protect indigenous communities. Nagan's analysis asks whether the regime of international human rights bodies, each with varying processes and procedures that cater to particular groups, is in fact capable of such an extension. Nagan suggests that the lack of a contextually appropriate international body for indigenous peoples can be understood to present substantive and procedural limitations on the international human rights implementation system. The analysis suggests that the development of an indigenous-specific framework that provides normative and procedural guidance on juxtaposing human rights with culturally sensitive capacity building would enable indigenous peoples to realize the common goal of sustainable self-determination.

Carolina Adler, Darryn McEvoy, Prem Chhetri, and Ester Kruk take these analyses of the role of indigenous knowledge further in their article "The role of tourism in a changing climate for conservation and development. A problem-oriented study in the Kailash Sacred Landscape, Nepal," with specific attention to coupling environmental preservation, sustainable development, and the achievement of economic benefits for the indigenous communities themselves. This article centers on an interdisciplinary study conducted in the Kailash Sacred Landscape region in Nepal and examines how economic co-benefits can be achieved through community-designed projects, such as sustainable ecotourism, which are developed and implemented according to their own needs and priorities, and using their traditional knowledge and resources. The result can be more effective stewardship of biodiversity and patrimonial land, and an influx of needed revenue for indigenous communities.

Finally, in "Enabling hybrid space: Epistemological diversity in socio-ecological problem-solving," M.J. Barrett reflects holistically on the challenge of integrating multiple knowledge systems into processes for improved socio-ecological decision-making and problem-solving, toward the promotion of long-term sustainability. Barrett's analysis springs from the growing recognition that Western scientific approaches may not be sufficient to solve complex problems related to sustainable environmental management and protection of biodiversity; indeed, it may even be that the assumptions and orientations implicit in Western culture further circumscribe hybrid approaches. Barrett suggests that Cartesian thinking has its place in problem-solving, but that its utility could be amplified when integrated with transrational ways of knowing.

McDougal et al. (1977) observed that "the peoples of the world, whatever their differences in cultural traditions and styles of justification, are today increasingly demanding the enhanced protection of all those basic rights, commonly characterized ... as those of human dignity." But even as scholars observe and document diluted and diminished 
conceptions of common interest, there remains powerful evidence for intrinsic interdependencies between the peoples of the earth. This collection seeks to provide empirical and methodological insight for the integration of epistemologically diverse perspectives into the common interest goals of environmental sustainability and human dignity.

\section{References}

Beckford, C. L., Jacobs, C., Williams, N., et al. (2010). Aboriginal environmental wisdom, stewardship, and sustainability: Lessons from the Walpole Island First Nations, Ontario, Canada. Journal of Environmental Education, 41, 239-248. doi:10.1080/00958961003676314.

Crutzen, P. J., \& Steffen, W. (2003). How long have we been in the Anthropocene? Climatic Change, 61, 251-257. doi:10.1023/B:CLIM.0000004708.74871.62.

Dei, G. J. S. (1993). Indigenous African knowledge systems-Local traditions of sustainable forestry. Singapore Journal of Tropical Geography, 14, 28-41.

Hansen, D. O., \& Erbaugh, J. M. (1987). The social dimension of natural resources management. In D. D. Southgate \& J. F. Disinger (Eds.), Sustainable resources development in the Third World (pp. 81-94). Boulder: Westview Press.

International Alliance of Indigenous-Tribal Peoples of the Tropical Forests. (1992). Charter of the Indigenous-Tribal Peoples of the Tropical Forests (established, Penang, Malaysia, 15 Feb 1992 and Revised, Nairobi, Kenya, 22 Nov 2002), Art. 45. Available at www.international-alliance.org/documents/ charter_eng.doc. Last visited December 8, 2012.

Lasswell, H. D. (1963). The future of political science. New York: Atherton Press.

Lasswell, H. D., \& McDougal, M. S. (1943). Legal Education and Public Policy: Professional Training in the Public Interest, 52 YALE L.J. 217.

McDougal, M. S., Chen, L.-C., \& Lasswell, H. D. (1977). Human Rights in World Public Order: Human Rights in Comprehensive Context. Northwestern Law Review, 72(2), p230.

McDougal, M. S., Lasswell, H. D., \& Reisman, W. M. (1968). Theories About International Law: Prologue to a Configurative Jurisprudence, 8 VA. J. INT'L L. 189, reprinted in Myres McDougal and W. Michael Reisman, International Law Essays 43 (1981).

Secretariat of the Convention on Biological Diversity. (2004). The Convention on Biological Diversity: From Conception to Implementation, CBD News Special Edition 29. Available at: https://www. cbd.int/doc/publications/CBD-10th-anniversary.pdf. Last visited December 8, 2012.

Vanek, E. (1989). Enhancing natural resources management in developing nations through improved attitudes towards indigenous knowledge systems: The case of the World Bank. In D. M. Warren, L. J. Slikkerveer, \& S. O. Titiilola (Eds.), Indigenous knowledge systems: Implications for Agricultural and International Development, Studies in Technology and Social Change (Vol. 11, pp. 162-170). Iowa: Iowa State University. 